\title{
Aggression of European Dark Bee and Possibility of its Decrease by Selection
}

\author{
Nikolay N. Grankin \\ Department of Zoology \\ Orel State University \\ Orel, Russian Federation
}

\author{
Svetlana N. Bakina \\ Department of Zoology \\ Orel State University \\ Orel, Russian Federation
}

\author{
Ekaterina A. Fomina \\ Department of Zoology \\ Orel State University \\ Orel, Russian Federation
}

\author{
Angela P. Tyapkina \\ Department of Zoology \\ Orel State University \\ Orel, Russian Federation
}

\author{
Tatyana V. Fedyaeva \\ Department of Zoology \\ Orel State University \\ Orel, Russian Federation
}

\begin{abstract}
The paper presents the results of the study of the adaptive behavioral trait of workers of European dark bees' subspecies. The significance of the study is due to the need to decrease the level of aggression of European dark bees and increase its adaptability. The materials of the paper are aimed at revealing the features of the demonstration of aggression of bees during the active period, the degree of its genotypic determination and the possibility of selection for a decrease. The individual selection of bee colonies was used with evaluation of queens for the quality of offspring, which made it possible to reduce the level of aggression of workers by an average of $32.8 \%$ over four generations of selection. The materials of the paper showed a positive correlation between the aggression of workers of European dark bees and their honey-producing capacity. The results of the study serve a useful purpose for beekeeping in the central and northern regions, where European dark bee colonies are located.
\end{abstract}

Keywords-european dark bees; aggression; genotypic determination; selection; honey producing capacity; individual selection.

\section{INTRODUCTION}

The subspecies of European dark bees, Apis mellifera mellifera L., is the most common of the known subspecies of honey bees. The native habitat of them in Russia extends throughout the central forest area, diverse in physicogeographical and honey extraction conditions. In this regard, the genotypic structure of European dark bee colonies, like no other subspecies, is extremely diverse. Some researchers $[1,2,3]$ showed the differentiation of European dark bees for a number of local populations, which creates great opportunities for breeding bee families according to different traits. In the complex of ethological traits of
European dark bees, there is a significant and problematic feature, which significantly limits their use in densely populated areas - aggression of workers is higher than that of other subspecies of bees [14]. The aggression of European dark bees as a trait is the response evolutionary developed in the forest and taiga conditions to the intervention in their lives of such natural violators as a bear, marten, and mouse.

Aggression as an ethological trait of European dark bees has drawn attention of many researchers. S.G. Petrov [6] noted the connection between the size of a big venom gland of European dark bees from Kashira and their honey-producing capacity. The author believed that the size of a big venom gland positively correlates with the intensity of metabolism and, in this connection, honey-gathering activity of bees. Unfortunately, the experimental data confirming this assumption of S.G. Petrov has not yet been received. Koryakov [4] also reported on the positive relationship between the strength of bee colonies, honey production and the maliciousness of European dark bees in the conditions of the Bryansk Region. E.M. Petrov [5] noted that the families of European dark bees, who have excessive malice, gather more honey, and therefore are more appreciated by local beekeepers of Bashkortostan. Similar information concerning the connection of maliciousness of European dark bees of Lithuania with honey production was provided by $\mathrm{Yu}$.V. Straigis [19]. According to his observations, bees with higher aggression gathered $7.1 \mathrm{~kg}$ of honey more than usual ones.

The aggression of bees significantly affects the productivity of beekeepers. Despite this, there is still no universally accepted scientifically validated methodology for its quantitative estimation, which makes it possible to have comparable data on the features of its manifestation. There are known methodological approaches of Stort [6, 7]. To determine the degree of aggression of Apis mellifera 
adansonii and its hybrids, the author used a $2 \mathrm{~cm}$ diameter leather ball filled with cotton and placed in front of a hive. The author judged about the aggression of bees from the moment of the beginning of the pendular oscillations of the ball to the moment when the bees began to attack him [16]. Other researchers used a plotting sheet to estimate aggression, which was placed over a rapidly opening bee-nest. By the number of stings on the surface of the plotting sheet, one could judge about the degree of aggression of the bees [17]. Long-term observations of European dark bees of the Oryol Region allow the authors to make some generalizations about the aggression of their workers and the peculiarities of its manifestation [11]. First of all, one should note an explicit dependence of the aggression of European dark bees on the conditions of growth, development, and honey sipping activity. Against the background of favorable conditions for bee colonies, the degree of aggression of their workers is significantly reduced. During honey gathering from buckwheat, raspberry, melilot, cornflower, when the daily weight gain of nectar in strong families exceeds $8-10 \mathrm{~kg}$, the aggression of bees is minimal. The scarcity of honeygathering conditions significantly intensifies the aggression of European dark bees and considerably complicates the work of beekeepers with them [12]. Taking into account the total number of bee colonies of this breed in Russia, the development of directions and methods to decrease the aggression of its workers becomes necessary [13]. The authors can note some solutions:

1. Artificial improvement of the honey-making base, the formation of continuous and relatively stable honeygathering conditions;

2. The selection of bee colonies for decreasing the aggression of their workers.

\section{MATERIALS AND METHODS}

The object of the study was European dark bees of the Orlovskiy species. The work was carried out on the basis of the Experimental Station of Beekeeping called "Orlovskaya". The aggression of workers of European dark bees was estimated according to the methodology of Stort $[6,7]$ and the number of bee stings during the surveys of brood in bee families every 12 days prior to the beginning of the main honey-gathering. The economically useful traits of bee colonies were studied according to the methods of the Research Institute of Apiculture [8,15]. The quantitative data were biometrically processed by Lakin [9].

\section{RESULTS}

In bee families, from 5 to 7 periodic surveys of the state of bee colonies were carried out, as well as the aggression of their workers. The process of registration for a bee family included: the opening of the nest, revision of all honeycombs, determination of the number of fodder reserves, registration of the number of brood, estimation of the general condition of the family and its needs. Inspection of one bee family took 4-6 minutes. At the same time, the behavior of the workers was determined and the number of stings during the full survey of the family was recorded. Weather and honey-gathering conditions of active periods were formed in different ways, which to a certain extent reflected the dynamics of aggression of workers and, in general, the productivity of honeybee families in honey and wax (Table 1).

TABLE 1. THE DYNAMICS OF AGGRESSION DEMONSTRATION AMONG EUROPEAN DARK BEES OF THE ORLOVSKIY SPECIES

\begin{tabular}{|c|c|c|c|}
\hline $\begin{array}{c}\text { Registration } \\
\text { dates }\end{array}$ & $\begin{array}{c}M \pm \mathbf{m}, \\
\text { stings }\end{array}$ & $\boldsymbol{\sigma}$ & $\lim$ \\
\hline \multicolumn{4}{|c|}{2006} \\
\hline April 19 & $1.4 \pm 0.32$ & 1.89 & $0-6$ \\
\hline May 01 & $1.6 \pm 0.26$ & 1.56 & $0-5$ \\
\hline May 14 & $2.1 \pm 0.33$ & 1.93 & $0-7$ \\
\hline May 26 & $2.7 \pm 0.35$ & 2.04 & $0-7$ \\
\hline June 9 & $0.9 \pm 0.18$ & 1.05 & $0-4$ \\
\hline June 21 & $1.6 \pm 0.24$ & 1.42 & $0-4$ \\
\hline July 4 & $1.1 \pm 0.18$ & 1.03 & $0-4$ \\
\hline Average & $1.6 \pm 0.27$ & 1.58 & $0-5.3$ \\
\hline \multicolumn{4}{|c|}{2007} \\
\hline May 10 & $1.8 \pm 0.25$ & 1.38 & $0-4$ \\
\hline May 22 & $1.2 \pm 0.21$ & 1.13 & $0-5$ \\
\hline June 4 & $2.2 \pm 0.29$ & 1.57 & $0-5$ \\
\hline June 16 & $3.1 \pm 0.36$ & 1.96 & $0-7$ \\
\hline June 28 & $3.4 \pm 0.41$ & 1.86 & $0-6$ \\
\hline Average & $2.3 \pm 0.30$ & 1.55 & $0-5.4$ \\
\hline \multicolumn{4}{|c|}{2009} \\
\hline June 5 & $4.6 \pm 0.58$ & 1.99 & $1-9$ \\
\hline June 17 & $2.6 \pm 0.53$ & 1.86 & $0-6$ \\
\hline June 29 & $2.9 \pm 0.45$ & 1.50 & $0-5$ \\
\hline July 11 & $1.8 \pm 0.38$ & 1.27 & $0-5$ \\
\hline July 23 & $1.3 \pm 0.35$ & 1.20 & $0-3$ \\
\hline Average & $2.6 \pm 0.36$ & 1.56 & $0.2-5.6$ \\
\hline
\end{tabular}

Synchronously with the conditions of development of bee families within each season, the degree of aggression of their bees changed as well. With the approach to the main honey gathering, with the increase of honey in the nests, the aggression of the workers declined. It is important to note that regardless of the weather and honey-gathering conditions in the studied groups there were bee colonies with the steadily peaceful behavior of individuals. Their number varied during different seasons from 9.1 to $49 \%$. Concerning the degree of genotypic determination of aggression, which determines the possibility of breeding bee families of a particular group, the authors note that it was $12-23 \%$ of the total level of variability of the trait. It was about the same level as the signs of productivity. The aggression of European dark bees, as an important behavioral trait, depends mainly on the conditions of development and honey-gathering activity, varying in different periods of the seasons from a complete peaceful disposition to a high degree of manifestation. The most promising areas for decreasing the aggression of bees include, first of all, sufficient and constant nectar excretion of flowering plants in the honey-gathering area and selection of bee colonies for decreasing the aggression of their workers.

In our studies, the necessary honey-gathering conditions for the bee colonies of the breeding group were achieved by bringing the apiaries to the forestry of the Orlovskoye Polesie to the natural thickets of ashberry, raspberry, buckthorn, 
swampy saber and other fairly abundant meadows, and then to entomophilous crops (buckwheat, phacelia, sunflower) in the farms of the Oryol Region.

An important direction is the formation of programmable honey flows by planting and sowing promising woody, shrubby and herbaceous honey plants with known terms and duration of blossom, high nectar extraction $[10,18]$. In the central part of Russia, about $33 \%$ of the territory is occupied by ravine plantations, which are little used in the renewable economic resources of the country. Filling this territory, as well as bare banks of large and small rivers, lakes, and ponds, with bee plants contributes to the enrichment of the honeygathering potential of Russia.

During the development of the selection program for European dark bees of the Orlovskiy species to decrease the aggression of their workers by $25-30 \%$ taking into account the initial level of genotypic determination of the trait $\left(\mathrm{h}^{2}=0.36\right)$, the individual selection of bee colonies was carried out with the evaluation of their queens on the quality of young [20]. Characterizing the intensity of the selection, the authors should note that at the initial stage, the average level of aggression of bee families $F_{1}$ was 160 stings, i.e. was 5.2 times less than from the workers of the source group (Table 2).

TABLE 2. CHANGES IN THE AGgRESSION OF EUROPEAN DARK BEES UNDER THE INFLUENCE OF SELECTION

\begin{tabular}{|l|c|c|c|c|}
\hline $\begin{array}{c}\text { Groups of } \\
\text { bee colonies }\end{array}$ & $\begin{array}{c}\text { Year of } \\
\text { test }\end{array}$ & $\begin{array}{c}\mathbf{M} \pm \mathbf{m ,} \\
\text { stings, pcs. }\end{array}$ & $\boldsymbol{\sigma}$ & $\lim$ \\
\hline Source group & 2009 & $1.1 \pm 0.30$ & 1.09 & $0-3.7$ \\
\hline $\mathrm{F}_{1}$ & 2010 & $0.9 \pm 0.14$ & 0.67 & $0-2.0$ \\
& 2011 & $1.0 \pm 0.18$ & 0.98 & $0-3.6$ \\
\hline Average $\mathrm{F}_{1}$ & & $0.95 \pm 0.16$ & 0.82 & $0-9.8$ \\
\hline $\mathrm{F}_{2}$ & 2012 & $0.7 \pm 0.12$ & 0.77 & $0-2.9$ \\
& 2013 & $0.5 \pm 0.14$ & 0.46 & $0-1.9$ \\
\hline Average $\mathrm{F}_{2}$ & & $0.6 \pm 0.13$ & 0.62 & $0-2.4$ \\
\hline $\mathrm{F}_{3}$ & 2014 & $0.6 \pm 0.20$ & 0.70 & $0-2.5$ \\
& 2015 & $0.7 \pm 0.09$ & 0.48 & $0-1.7$ \\
\hline Average $\mathrm{F}_{3}$ & & $0.7 \pm 0.15$ & 0.59 & $0-2.1$ \\
\hline $\mathrm{F}_{4}$ & 2016 & $0.8 \pm 0.3$ & 0.80 & $0-3.2$ \\
& 2017 & $0.8 \pm 0.04$ & 0.10 & $0-2.6$ \\
\hline Average $\mathrm{F}_{4}$ & & $0.8 \pm 0.06$ & 0.45 & $0-2.9$ \\
\hline
\end{tabular}

The average level of the feature to be selected in $F_{1}$ workers over 2 seasons of tests, which amounted to 0.95 stings per one bee family, decreased by an average of $13.6 \%$ compared to the baseline. The bee colonies - the ancestors of the next $F_{2}$ generation were selected from the young $F_{1}$ with an average level of aggression of 0.28 workers per family, i.e. 3.6 times smaller than that of the bees $F_{1}$. As a result, the average level of aggression of worker bees of the $F_{2}$ young was 0.61 stings, which is $35.8 \%$ lower than the level of the bees of the previous generation. In the workers of the families of the $\mathrm{F}_{3}$ ancestors, the average level of aggression was 0.45 stings, which is $26 \%$ lower than the average level of traits of the bees of the previous generation. The level of aggression of workers of $\mathrm{F}_{3}$ offspring, which averaged 0.7 stings per bee family, was not significantly different from that of the bees of $\mathrm{F}_{3}$ offspring. In the bee colonies of $\mathrm{F}_{4}$ offspring, the average level of aggression, which averaged 0.8 stings per family, also was unreliably different from the size of the bees of the previous generation.

Dynamics of aggression of European dark bees in the selection process testifies to its highest effectiveness at the stage of $F_{2}$ offspring evaluation. The decrease in the rates of the aggression of working individuals of $F_{3}$ and $F_{4}$ offspring is to a certain extent due to a decrease in the degree of its genotypic diversity as a result of intensive selection, which is shown by a decrease in the values of the heritability factor from 0.36 in the bees of the source group to 0.24 and 0.19 in the offspring of $\mathrm{F}_{3}$ and $\mathrm{F}_{4}$ [21].

The proposed breeding program is expected to reduce the level of aggression by $25-30 \%$ while maintaining the level of economic traits of European dark bee colonies typical of the source group. In connection with this, when each new generation was received, bee colonies were selected for the father and mother groups, in which low aggression of the workers was combined with high winter hardiness, increased average daily egg production of the queens, high honey and wax productivity of the bee colonies. As a result, European dark bee colonies with the decreased aggression of workers, the sizes of the main economic traits differed insignificantly from the families of the bees of the source group (Table 3).

The conditions for the growth and development of the bee colonies of the selected group, the realization of their productive qualities in different periods of testing were different. A marked deviation in bee colonies with the decreased aggression of workers from the source group was observed in honey production.

\section{DISCUSSION}

The reason for the decrease in honey-gathering activity of bees with decreased aggression could be some deterioration during the last years of weather and honey-gathering conditions in the spring-summer periods. The bee colonies of the selected group, which reached great strength by the periods of the basic honey gathering with buckwheat, could not fully demonstrate their potential productive qualities, due to unfavorable weather conditions. It is not excluded that the decrease in aggression under the influence of the conducted selection led to a decrease in the level of honey-gathering activity. A positive correlation between the aggression of European dark bees and their productivity was noted by S.G. Petrov [6] and E.M. Petrov [5]. Our research showed that a decrease in the aggression of Orlovskiy European dark bees' colonies under the influence of selection on average by $32.7 \%$ led to a decrease in their honey production by $28.5 \%$. Previously, some researchers noted the positive correlation between the aggression of European dark bees and their honey production. It was confirmed in our work.

An increase in the composite of highly productive genotypes of European dark bees' colonies leads to an increase in the aggression of their workers, which is more clearly manifested against the background of unfavorable weather and honey-gathering conditions. 
TABLE 3. TRAITS OF EUROPEAN DARK BEE COLONIES WITH THE DECREASED AGGRESSION OF WORKERS

\begin{tabular}{|c|c|c|c|c|c|c|c|}
\hline $\begin{array}{c}\text { Groups of } \\
\text { bee colonies }\end{array}$ & $\begin{array}{c}\text { Year of } \\
\text { test }\end{array}$ & $\begin{array}{l}\text { Aggression, } \\
\text { stings, pcs. }\end{array}$ & $\begin{array}{c}\text { Feed } \\
\text { consumption for } \\
\text { winter, kg } \\
\end{array}$ & $\begin{array}{c}\text { Seam of bees } \\
\text { between two } \\
\text { combs, for winter }\end{array}$ & $\begin{array}{l}\text { Maximum daily average } \\
\text { egg production of mother } \\
\text { bees, eggs, pcs. }\end{array}$ & $\begin{array}{c}\text { Honey } \\
\text { productivity, } \\
\text { kg } \\
\end{array}$ & $\begin{array}{c}\text { Wax } \\
\text { productivity, } \\
\text { honeycombs, pcs. }\end{array}$ \\
\hline Source group & 2009 & 1.10 & 9.8 & 1.1 & 2074 & 40.5 & 9.3 \\
\hline $\mathrm{F}_{1}$ & $\begin{array}{l}2010 \\
2011\end{array}$ & $\begin{array}{l}0.90 \\
1.00\end{array}$ & $\begin{array}{l}8.0 \\
7.2\end{array}$ & $\begin{array}{l}1.6 \\
1.2\end{array}$ & $\begin{array}{l}1872 \\
2250\end{array}$ & $\begin{array}{l}28.6 \\
26.0\end{array}$ & $\begin{array}{c}7.3 \\
10.4\end{array}$ \\
\hline Average $\mathrm{F}_{1}$ & & 0.95 & 7.6 & 1.4 & 2061 & 27.3 & 8.9 \\
\hline $\mathrm{F}_{2}$ & $\begin{array}{l}2012 \\
2013\end{array}$ & $\begin{array}{l}0.68 \\
0.54\end{array}$ & $\begin{array}{l}9.5 \\
8.9\end{array}$ & $\begin{array}{l}1.1 \\
0.7\end{array}$ & $\begin{array}{l}2036 \\
2204\end{array}$ & $\begin{array}{l}32.0 \\
26.1\end{array}$ & $\begin{array}{c}7.8 \\
11.2\end{array}$ \\
\hline Average $\mathrm{F}_{2}$ & & 0.61 & 9.2 & 0.9 & 2120 & 29.1 & 9.5 \\
\hline $\mathrm{F}_{3}$ & $\begin{array}{l}2014 \\
2015\end{array}$ & $\begin{array}{l}0.60 \\
0.65\end{array}$ & $\begin{array}{l}8.5 \\
6.6\end{array}$ & $\begin{array}{l}1.3 \\
0.8\end{array}$ & $\begin{array}{l}2085 \\
2152\end{array}$ & $\begin{array}{l}31.0 \\
22.5\end{array}$ & $\begin{array}{l}9.9 \\
5.2\end{array}$ \\
\hline Average $\mathrm{F}_{3}$ & & 0.63 & 7.6 & 1.1 & 2119 & 26.8 & 7.6 \\
\hline $\mathrm{F}_{4}$ & $\begin{array}{l}2016 \\
2017\end{array}$ & $\begin{array}{l}0.81 \\
0.76\end{array}$ & $\begin{array}{l}9.4 \\
8.2\end{array}$ & $\begin{array}{l}1.5 \\
0.7\end{array}$ & $\begin{array}{l}2050 \\
2025\end{array}$ & $\begin{array}{l}24.5 \\
41.3 \\
\end{array}$ & $\begin{array}{c}3.7 \\
11.9\end{array}$ \\
\hline Average $\mathrm{F}_{4}$ & & 0.79 & 8.8 & 1.1 & 2038 & 32.9 & 7.8 \\
\hline
\end{tabular}

Effective use of European dark bees' colonies with the decreased aggression of workers suggests the organization of favorable honey-gathering conditions due to crops and plantings, wild and cultivated honey plants - abundant producers of pollen and nectar.

\section{CONCLUSION}

The aggression of European dark bees as an important ethnological trait largely depends on the conditions of their growth, development and honey-gathering activities. In the conditions of industrial beekeeping, this adaptive feature of bee colonies reduces the productivity of the work of beekeepers and requires certain measures to change it. The most promising ways for decreasing the aggression of bees: (1) Improvement of honey-gathering conditions due to optimization of the species composition of honey-making plants; (2) Selection of bee colonies for decreasing the aggression of workers.

Due to the insignificant degree of genotypic determination of aggression bees, individual selection of bee colonies is based on the breeding program for its reduction, with evaluation of queens for the quality of brood. In the group of European dark bee families of the Orlovskiy species, it was possible to decrease the aggression of working individuals by $25-33 \%$ for three generations of intensive individual selection. The number of bee colonies with the decreased aggression of working individuals, which are typical for European dark bee breed with high winter hardiness, intensive growth, and development during the active period, had the decreased honey production by an average of $28.2 \%$. Effective use of European dark bee colonies with the decreased aggression of workers is most promising in the large-scale industrial beekeeping in the central and northern regions of the European part of Russia, the Urals and Siberia.

\section{References}

[1] A. Avalos, Y. Rodríguez-Cruz, and T. Giray, "Individual responsiveness to shock and colony-level aggression in honey bees: evidence for a genetic component," Behavioral Ecology and Sociobiology, vol. 68, No. 5, pp. 761-771, 2014.

[2] G.A. Avetisyan, "Some issues of evolution, dispersal, protection, and use of species of bees," in 17th International Congress on Beekeeping. Moscow: Selkhozgiz, 1958, pp. 57-62.
[3] G.O. Babarinde, S.A. Babarinde, D.O. Adegbola, and S.I. Ajayeoba, "Effects of harvesting methods on physicochemical and microbial qualities of honey," Journal of Food Science and Technology, vol. 48, No. 5, pp. 628-634, 2011.

[4] D.V. Koryakov, "Characteristics of Caucasian bees", Beekeeping, No. 8-9, pp. 408-409, 1927.

[5] E.M. Petrov, Bashkirian Wild Hive Bee. Ufa: Bashkirskoye knizhnoye izdatelstvo, 1970, pp. 64-83.

[6] S.G. Petrov. "The big poisonous iron of working bees as an indicator of the productivity of bee colonies, Experienced apiary", No. 1-2, pp. 57 $-59,1927$

[7] A.S. Stort, "Genetic study of aggressiveness of two subspecies of Apis mellifera in Brazil 1. Some tests to measure aggressiveness," Journal of Apicultural Research, vol. 13, no. 1, pp. 33-38, 1974.

[8] A.S. Stort, "Genetic study of aggressiveness of two subspecies of Apis mellifera in Brazil. 2. Time at which the first sting reached a leather ball," Journal of Apicultural Research, vol. 14, no. 3-4, 171-175, 1975.

[9] A.V. Borodachev, A.N. Burmistrov, A.I. Kasyanov, and L.S. Krivtsov, Methods of Carrying out Scientific Research in Beekeeping]. Rybnoe: NIIP, 2006.

[10] G.F. Lakin, Biometrics. Moscow: Vysshaya shkola, 1990.

[11] N.N. Grankin, and S.N. Averina, "About one methodical approach in the selection of the Central Russian bees on the decrease of acrimony," Scientific Notes of Orel State University, no. 6(56), pp. 156-159, 2013.

[12] S.N. Bakina, "Aggression of European dark bees and features of its manifestation," Beekeeping, No. 1, pp. 27-29, 2016.

[13] N.I. Krivtsov, and N.N. Grankin, Central Russian Bees and Their Selection. Rybnoe: NIIP, 2004.

[14] A.I. Monakhov, N.I. Krivtsov, and L.N. Orinich, "Comparative test of some populations of Central Russian bees," Beekeeping, No. 10, pp. 13, 1976.

[15] I. Pihler, Bee selection and queen bee breeding, M.Sc. thesis. Novi Sad (Serbia): Univerzitet u Novom Sadu, 2008.

[16] A.M. Pereira, and J. Chaud-Netto, "Africanized honeybees: Biological characteristics, urban nesting behavior and accidents caused in Brazilian cities (Hymenoptera: Apidae)," Sociobiology, vol. 46, No. 3, pp. 535-550, 2005 .

[17] A.N. Pearce, Z.Y. Huang, and M.D. Breed, "Juvenile hormone and aggression in honey bees," Journal of Insect Physiology, vol. 47, No. 11, pp. 1243-1247, 2001.

[18] A. Rortais, D. Tentcheva, A. Papachristoforou, M.E. Colin, and M. Bergoin, "Deformed wing virus is not related to honey bees' aggressiveness," Virology Journal, vol. 3, p. 61, 2006.

[19] Yu.V. Straigis. "Morphological signs and some properties of the bees of the Lithuanian population", Moscow: Kolos, pp. 41, 1975

[20] D.R. Smith, "African bees in the Americas: Insights from biogeography and genetics," Trends in Ecology and Evolution, vol. 6, No. 1, pp. 1721, 1991.

[21] J.W. Van Veen, "Beekeeping practices for management of africanized bees," in Beekeeping for Poverty Alleviation and Livelihood Security: Vol. 1: Technological Aspects of Beekeeping. Springer, 2014, pp. 193203. 